chiaux résultant surtout par fusion centrique des chromosomes monobranchiaux habituels chez le chien. Dans les deux sexes, de nombreuses cellules tumorales interphasiques portent un chromocentre ressemblant au corpuscule $\mathrm{X}$ de BARR.

Les différences dimensionnelles entre ces chromocentres semblent évoquer des causes différentes pour leur formation :

r) contamination des cellules à deux chromosomes $\mathrm{X}$ par le virus;

2) prolifération sélective de certaines lignées cellulaires;

3) fusion centrique par translocation d'un chromosome $X$ sur un autre chromosome ou fragment chromosomique, ainsi que cela semble ressortir de la technique de dénaturation thermique ménagée (bandes $R$ de DUTRILLAUX et LEJEUNE, 197I).

\title{
R-banding patterns of the dog chromosomes
}

\author{
M. HAGELTORN \\ Department of Animal Genetics, Nutrition and Hygiene, \\ Royal Veterinary College, HVC, S-750 o7 Uppsala 7 (Sweden)
}

Identification of individual chromosome pairs of the dog karyotype have been impossible using conventional staining techniques due to the existence of a high chromosome number $(2 n=78)$ and a karyotype containing only acro- or telocentric autosomes. The $Q$ and the $G$ techniques have not made possible accurate identification of all pairs. With a combined $Q$ and $\mathrm{R}$ staining technique after $\mathrm{BudR}$ incorporation all pairs of chromosomes are easily identified. The $Q$ - and $\mathrm{G}$-banding patterns are described.

\section{Remarks on Identification of $\mathrm{X}$ chromosome in Pig}

\author{
P. SYSA \\ Laboratorium Cytogenetycine, Szkola Glowna Gospoderstwa \\ Wiejskiego, Akadema Plonocza WWarzawa \\ Wydzial Weterynarjny Instytut Fizjocogil Zwierzat (Poland)
}

Identification of $\mathrm{X}$ chromosome in pig is still very controversial. Karyotype of pig was investigated by visualising $G$ bands after treatment with trypsin. The fluorescence pattern of $R$ bands was evaluated after application of BUDR and staining with acridine orange.

Occurrence of fluorising $\mathrm{R}$ band at the end of $p$ arm of $\mathrm{X}$ chromosome suggested to be the identifing feature of this sex chromosome in pig.

\section{The effect of Feeding Various Levels of Aflatoxin $B_{1}$ on the chromosome Pattern of Rats and Pigs}

\author{
L. LOJDA and V. PETRICKOVA \\ Veterinary Research Institute, Brno, Tchekoslovaquie
}

Inadequate storage and handling of feeds under intensive husbandry conditions may result in their contamination with moulds, among which Aspergillus flavus, producing a flatoxin, is a hazard in particular. To date, the data on negative effects of aflatoxin on chromosome pattern have been scanty, being based merely on the effects produced by its addition to human lung cell culture.

In our experiments a flatoxin $B_{1}$ was fed to rats and pigs at various dose levels ranging from 4 ppm to $L D_{50}$ for varying lengths of time to investigate its effects in vivo. In addition to a considerable effect on reproductive performance, the low doses produced mainly numerical aberrations, the medium ones were responsible in addition for structural aberrations and the $L_{4} D_{50}$ produced various types of marked structural aberrations in more than 75 per cent of all cells. 